\title{
Türkiye İnşaat Sektöründe 2016 ve 2017 Yıllarında Meydana Gelen İş Kazalarının İstatistiksel Olarak Karşılaştırılması
}

\author{
Statistical Comparison of The Work Accidents in Turkish Construction Sector in Year Of \\ 2016 and 2017
}

\author{
Oğuz UZDíl ${ }^{1}$ (D), Arif Nihat GÜLLÜOĞLU ${ }^{1}$ (iD) \\ ${ }^{1}$ Marmara Üniversitesi, Fen Bilimleri Enstitüsü, İş Güvenliği Anabilim Dall, İstanbul.
}

\begin{abstract}
$\ddot{O} \mathbf{z}$
Ülkemizde yapılmakta olan inşaat sayılarındaki artış, iş kazası miktarlarını da oldukça yakından etkilemektedir. Gerekli önlemlerin alınmasındaki ihmal, fazla ve yoğun mesai süresi, aşırı özgüven, yeterli iş sağlığı ve güvenliği eğitimlerinin verilmemesi inşaat alanlarındaki kazaları tetiklemektedir. Bu çalışmada, 2017 yılında meydana gelen kazalar, 2016 yılında meydana gelen kazalarla karşılaştırılarak incelenmiştir. Bu inceleme için Sosyal Güvenlik Kurumu (SGK) 2016 ve 2017 yıllarının verileri esas alınmıştır. SGK verilerine dayanarak inşaat sektörü; bina inşaatı, bina dışı yapıların inşaatı ve özel inşaatlar olmak üzere üç alt kategori olarak değerlendirilmiştir. Bu incelemeler sonucunda 2017'de inşaat sektöründe yaşanan iş kazalarının 2016'ya oranla arttığı ve bunun sonucunda ölüm sayısında da yükselme olduğu gözlemlenmiştir.
\end{abstract}

Anahtar Kelimeler: İnşaat Sektörü, İş Güvenliği, Kaza İstatistikleri, İş Kazaları

\begin{abstract}
The increase in the number of construction in our country also affects the number of accidents very closely. The negligence to take required precautions overtime, excessive self-confidence and lack of adequate occupational health and safety trainings triggers accidents at construction sites. In this study, the accidents occurred in 2017 were compared with the accidents that occurred in 2016. This review is based on Social Security Institution (SGK) 2017 and 2016 data. Based on the SGK data, the construction sector has been evaluated in three sub categories: building construction, constructions besides buildings and private constructions. As a result of these investigations, it was observed that the number of work accidents in the construction sector increased in 2017 compared to 2016 and the number of deaths increased as a result.

Keywords: Construction Sector, Occupational Safety, Accident Statistics, Work Accidents
\end{abstract}

\section{GİRIS}

İnşaat sektörü, ekonomiye sağladığı katma değer ve istihdam olanakları açısından lokomotif sektör olma özelliği taşımaktadır. Dünyanın birçok ülkesinde olduğu gibi ülkemiz inşaat sektöründe de yaşanan iş kazaları büyük sorun teşkil etmektedir. Sosyal Güvenlik Kurumu istatistiklerine göre inşaat sektörü Türkiye'de yaşanan iş kazalarının sayıca fazla olduğu ilk üç sektör arasında bulunmasının yanı sıra, can kayıpları açısından tüm sektörler içerisinde ilk sırada yer almaktadır. 2016 yılı SGK verilerine göre Türkiye'de bulunan 1 milyon 749 bin 240 iş yerinin 195 bin 990 ' 1 inşaat sektörünü kapsamaktadır. Tüm sektörlerde çalışanların \%13,7'si inşaat sektöründe istihdam edilmektedir. İş kazalarının $\% 15,6$ 'sı ekonomi ve istihdam açısından büyük önem taşıyan inşaat sektöründe yaşanmış olup, ölümlü iş kazaları bakımından sektör $\% 35,3^{\prime}$ lük oranla tüm faaliyet alanları içerisinde ilk sırada yer almaktadır [1].

İnşaat sektöründe yaşanan yüksek kaza oranları ve ağırlığı dikkate alınarak Çalışma ve Sosyal Güvenlik Bakanlığınca 2012 yılında yayımlanan “İş Sağlığı ve Güvenliğine İlişkin İşyeri Tehlike Sınıfları Tebliği”ne göre işyerlerinin ekonomik faaliyet alanlarına ilişkin tehlike sınıflarında inşaat sektörü "çok tehlikeli" sınıfına giren iş̧ kolları arasında yer almaktadır [2]. Bu nedenle inşaat sektörü ile ilgili kazalar kritik olaylardır ve temel nedenlerini anlamak ve tanımlamak için analiz edilmeleri gerekmektedir [3]. 
Ülkemizde faaliyet gösteren işyerlerinin geneli ve inşaat sektörünün $\% 98$ 'i çalışan sayısı elliden az olan mikro ve küçük ölçekli işletme özelliğinde iken, çalışanların \%60'1 bu işletmelerde istihdam edilmektedir. İnşaat sektörü kendi alt grupları içinde değerlendirildiğinde, işyeri sayıs1 \%66 oranla en fazla "bina inşaatı" alt grubunda olup, çalışan sayısına göre sektör içindeki payı \%64', yaşanan iş kazaları bakımından ise $\% 56$ ' lık kısmı bu alt sektörde yer almaktadır. İnşaat sektörü içinde yol, su, köprü, tünel ve elektrik şebekesi inşaatı gibi "bina dışı yapıların inşaatı" alt grubunda $\% 7$ olan işyeri sayılarında $\% 20$ çalışan olmasına rağmen yaşanan iş kazası oranı $\% 33$, ölüm oranı ise \%27 olarak gerçekleşmiştir. Bu veriler, inşaat sektöründe çalışan sayısı başına düşen iş kazası ve ölüm sayısı yüzdelik değerlerine göre, "bina dışı yapıların inşaatı" alt sektöründe kazaların daha yoğun ve ağır yaşandığını göstermektedir [4].

Türkiye'de 2014 ve 2015 yıllarında meydana gelmiş iş kazaları verilerinin analiz sonuçlarına göre, 26-35 yaş aralığındaki erkeklerin, bir ay ile bir yıl arasında iş tecrübesine sahip çalışanların, nitelik gerektirmeyen işlerde çalışanların daha fazla iş kazası geçirdiği tespit edilmiştir. İnşaat ve sanayi alanlarında ise iş kazası ve ölüm sayısının daha fazla olduğu belirtilmiştir [5]. Kuzey Yuanistan'da yapılan bir çalışmada, inşaat sektörü ile ilgili en sık karşılaşılan kazalar araştırılmış ve kazaların çeşitli parametreleri arasındaki ikişkiler belirlenmiştir. Araştırma sonucunda kazaya uğrayanların çoğunlukla 22-44 yaş arası deneyimsiz personel olduğu, en çok görülen kaza tipinin düşme şeklinde gerçekleştĭgi, erkeklerin kadınlara göre ölümcül yaralanmalara daha çok maruz kaldığ 1 , kazaların çoğunlukla sabah saatlerinde gerçekleştiği saptanmıştır [3].

İnşaat sektöründe meydana gelen iş kazalarının analiz edilmesi ve bu kazaların etkilerinin incelenmesi sonucunda, iş kazalarının \%88 oranında tehlikeli hareketler, $\% 10$ oranında tehlikeli koşullar ve $\% 2$ oranında kaçınılmazlık nedeni ile meydana geldiği gösterilmiştir [6]. Türkiye'de inşaat sektöründe en fazla meydana gelen iş kazaları bina, tünel, kanal ve yol inşaatı olarak sınıflara ayrılmış ve bu kazaların nedenleri üzerinde durulmuş, bu nedenler araştııılırken şantiye farklılıklarının da göz önünde bulundurulması gerektiği belirtilmiş̧ir [7]. 2015 Ocak ile 2017 Kasım tarihleri arasında şantiyelerde yaşanan 107 iş kazasının incelemesi sonucunda üstyapı şantiyelerinde meydana gelen kazaların altyapı şantiyelerine oranla daha fazla olduğu tespit edilmiştir [8].

Şantiyelerde meydana gelen kazalar, insanların, nesnelerin veya materyallerin taşınması sırasında mülklerin zarar görmesine veya insanların yaralanmasına neden olabilecek planlanmamış olaylardır. Kazaların çoğu güvensiz davranışlar ve güvensiz koşullar nedeniyle meydana gelmektedir.
İnşaat işyerlerindeki tüm tehlikelerin tanımlanması ve ortadan kaldırılması her zaman mümkün olmadığından, kritik verilerin toplaması için etkili kaza araştırma yöntemleri şarttır. İnşaat kazaları, sadece kaza nedenleri teorileri ve insan hataları teorileri gibi kaza inceleme teknikleriyle mümkün olan kazaların temel nedenlerini belirleyerek önlenebilmektedir. $\mathrm{Bu}$ teoriler kazaların neden meydana geldiğine dair fikir vermektedir [9].

Doğru önlemler ancak tehlikelerin tanımlanması, ortaya çıkan risklerin doğru ve kapsamlı bir şekilde belirlenmesi ile saptanabilir. Bununla birlikte, risk değerlendirmesinin bir işyerindeki tehlikeleri kısa sürede gidermesi beklenmemelidir. Aksine, bu uzun vadeli kalıcı bir çalışma ile elde edilebilir. Dolayısıyla temel prensip sürekli iyileştirme olmalıdır. Yöneticiler için kuruluştaki tehlikeler ve riskler hakkında eğitim ve iletişimi teşvik etmeleri de büyük önem taşımaktadır. $\mathrm{Bu}$ şekilde personel arasında risk bilinci artacaktır ve tehlikeleri ortadan kaldırmak için aktif katkıyı teşvik edecektir [10].

İnşaat sektöründeki sayıca fazla olan iş kazalarının azaltılması için önlemler alınması gerekmektedir. $\mathrm{Bu}$ önlemleri alabilmek için öncelikle iş sağlığı ve güvenliği, iş kazası kavramlarının iyi bilinmesi gerekmektedir.

\section{1. İş Sağlığı ve Güvenliği Kavramı}

İş sağllğı ve güvenliğinin modern ve geleneksel anlamda iki tanımlaması bulunmaktadır. Geleneksel olarak yapılan tanım: "iş yerlerini işin işleyişi sebebiyle oluşan tehlikelerden uzaklaştırmak ve sağllğa zarar verebilecek durumlardan arındırarak, çalı̧̧ma ortamını iyileştirmek amacıyla yapılan sistematik çalışmalar" dır. Diğer bir tanım olan modern tanım ise; "iş görenleri işin uygulanması esnasında ortaya çıkan sağlığa zararlı koşullardan ve güvenliği bozacak durum ve davranışlardan korunmak, üretimin sürekliliğini sağlamak ve verim düzeyini artırmak amaciyla yürütülen sistematik ve bilimsel çalışmalar" dır [5]. İş Sağlığı ve güvenliği çalışmalarında öncelikle çalışanların sağlık ve güvenliğinin, daha sonra üretim ve işletme güvenliğinin sağlanması konuları ele alınmaktadır [11].

\section{2. İş Kazası Kavramı}

Dünya Sağlık Örgütü (WHO) tarafından iş kazası: "önceden planlanmamış, genellikle yaralanmalara, makine ve materyalin zarar görmesine veya üretim sürecinin duraklamasına neden olan olay" olarak tanımlanmaktadır. Uluslararası Çalışma Örgütü (ILO) ise iş kazasını "belirli bir zarar veya yaralanmaya sebebiyet veren, planlanmamış öngörülemeyen bir olay" şeklinde tanımlamaktadır [12]. 6331 sayılı İş Sağlığı ve Güvenliği Kanunu'na göre iş kazası: “iş 
yerinde veya işin uygulanması sebebiyle ortaya çıkan, ölüme neden olan veya vücut bütünlügünü ruhen ya da bedenen engelli hale getiren olay" olarak tanımlanmaktadır [11].

İş yerlerinde insan sağllğı üzerinde doğrudan ve dolaylı olarak etkilere yol açabilen fiziksel, kimyasal, mekanik ve ergonomik faktörler bulunmaktadır. İşyerindeki bu olumsuz çalışma koşullarının etkilerinden dolayı iş kazaları meydana gelmektedir. İş kazalarının oluşmasında üretim teknolojisi, üretim araçları, çevre koşulları, sosyolojik, psikolojik, fizyolojik birçok etken rol oynamaktadır. İş kazalarının oluşmasına neden olan etkenler temelde, işyerlerindeki güvensiz durumlar ile çalışanların yaptığı güvensiz davranışlardan kaynaklanmaktadır.

\subsection{Dünya'da ve Türkiye'de İș Sağlığı ve Güvenliği}

18. yüzyılın ilk yarısından itibaren İngiltere'de başlayan sanayi devrimi ile üretim süreci büyük değişime uğramış, ilk evrede atölyelere daha sonra da gelişen teknoloji ile büyük makinelerin yer aldığ fabrika sistemine geçiş yaşanmıştır. İşverenlere bağlı, ücrete tabi çalışan işçi sayısı zamanla artmış ve bu sınıfın çalışma şartları, yapılan işlerin ortaya çıkardığı riskler, kazaları ve birtakım sağlık ve güvenlik sorunlarını da beraberinde getirmiştir. Çalışma ve hayat koşullarını daha iyi hale getirmek, çalışanların sağlığını güvence altına almak ve iş güvenliğini sağlamak için gerçekleştirilen birçok yasal düzenlemeler, Avrupa'daki diğer ülkeler için de emsal teşkil etmiştir. Başlangıçta Birleşmiş Milletlere bağlı bir organizasyon olarak kurulan Uluslararası Çalışma Örgütü (ILO) 1919 yılında kurulmuştur. Daha sonra Birleşmiş Milletler ile imzalanan bir antlaşma ile 1946 yılında bağımsız bir kuruluş şekline getirilmiştir [13].

Çalışanların, iş kazası ve meslek hastalıklarına karşı korunmasını amaçlayan ilk yasal organizasyonlar 19.yy sonlarında karşımıza çıkmaktadır. Türkiye'de çalışma hayatını düzenleyen ilk iş kanunu, 1936 tarihli 3008 sayılı İş Kanunu'dur. Bu kanun iş sağlığı ve güvenliği konusunda düzenlemeler içermektedir [13]. Türkiye'de İşçi Sağlığı Genel Müdürlüğü 1945 yılında kurulmuştur. Çalışma ve Sosyal Güvenlik Bakanlığına bağlı olarak faaliyette bulunan kuruluş, 2000 yılında yeniden yapılandırılarak İşçi Sağlığı ve Güvenliği Genel Müdürlüğü olarak değiştirilmiştir [14]. 2012 yılında yürürlüğe giren 6331 sayılı İş Sağlığı ve Güvenliği Kanunu, çalışan ve işverenler için önemli düzenlemeler içermektedir [15]. 6331 sayılı Kanunun amacı, işyerlerinde iş sağlığı ve güvenliğinin sağlanması ve mevcut sağlık ve güvenlik şartlarının iyileştirilmesi için işveren ve çalışanların görev, yetki, sorumluluk, hak ve yükümlülüklerini düzenlemektedir [11]. Bu kanun ile birlikte kamu ve özel sektör ayrımı yapılmadan tüm kazalar değerlendirilmektedir [6].

Bu çalışmada, 2016 ve 2017 yıllarında meydana gelen iş kazaları, meslek hastalıkları ve bunlara bağlı ölüm oranları incelenerek değerlendirilmesi yapılmıştır. SGK verilerine dayanarak inşaat sektörü bina inşaat1, bina dışı yapıların inşaatı ve özel inşaatlar olmak üzere üç alt kategori olarak değerlendirilmiştir.

\section{YÖNTEM}

$\mathrm{Bu}$ çalışmada SGK tarafindan yayınlanan Türkiyede faaliyet gösteren tüm sektörlerin toplamı ile İnşaat sektöründe meydana gelen iş kazalarının 2016 ve 2017 yıllarına ait verileri istatistiksel olarak karşılaştırılmıştır. Kullanılan SGK verileri 2013-2017 yılları arasını kapsamaktadır ve 4A güvencesine sahip çalışanları içermektedir. $\mathrm{Bu}$ veriler analiz edilerek değerlendirilmeye çalışılmıştır.

\section{BULGULAR}

Türkiye'de inşaat sektöründe en çok meydana gelen kaza tipleri sırasıyla Tablo 1'de verilmiştir.

Tablo 1. Türkiye'de inşaat sektöründeki başlıca kaza tipleri [16]

\begin{tabular}{rccccccc}
\hline \multirow{2}{*}{ No } & Ana Gruplar & \multicolumn{2}{c}{ Ölüm } & \multicolumn{2}{c}{ Yaralanma } & \multicolumn{2}{c}{ Toplam } \\
\cline { 2 - 8 } & Kaza Tipi & Sayı & \% & Sayı & \% & Sayı & \% \\
\hline 1 & İnsan Düşmesi & 1028 & 42,9 & 934 & 32,9 & 1962 & 37,4 \\
2 & Malzeme Düşmesi & 251 & 10,5 & 278 & 9,8 & 529 & 10,1 \\
3 & Malzeme Sıçraması & 10 & 0,4 & 211 & 7,4 & 221 & 4,2 \\
4 & Kazı Kenarının Göçmesi & 138 & 5,8 & 53 & 1,9 & 191 & 3,6 \\
5 & Yapı Kismının Göçmesi & 167 & 7,0 & 73 & 2,6 & 240 & 4,6 \\
6 & Elektrik Çarpması & 293 & 12,2 & 80 & 2,8 & 373 & 7,1 \\
7 & Patlayıcı Madde Kazaları & 50 & 0,2 & 82 & 2,9 & 132 & 2,5 \\
8 & Yapı Makinesi Kazaları & 206 & 8,6 & 97 & 3,4 & 303 & 5,8 \\
9 & Uzuv Kaptırma & 1 & 0,0 & 604 & 21,3 & 605 & 11,5 \\
\hline
\end{tabular}




\begin{tabular}{cccccccc}
\hline 10 & Uzuv Sıkışması & 1 & 0,0 & 200 & 7,0 & 201 & 3,8 \\
11 & El Aleti ile Ele Vurma & 0 & 0,0 & 42 & 1,5 & 42 & 0,8 \\
12 & Sivri Uçlu Keskin Ken. Cis. Yara. & 0 & 0,0 & 75 & 2,6 & 75 & 1,4 \\
13 & Şantiye İçi Trafik Kazaları & 168 & 7,0 & 38 & 1,3 & 206 & 3,9 \\
14 & Diğer Tip Kazalar & 85 & 3,5 & 74 & 2,6 & 159 & 3,0 \\
& Toplam & $\mathbf{2 3 9 8}$ & $\mathbf{1 0 0 , 0}$ & $\mathbf{2 8 4 1}$ & $\mathbf{1 0 0 , 0}$ & $\mathbf{5 2 3 9}$ & $\mathbf{1 0 0 , 0}$ \\
\hline
\end{tabular}

Kaza türleri incelendiğinde, inşaatlarda insan düşmesi tipindeki kaza tipi en başta gelmektedir. Bunun nedeni gerekli önlemlerin alınmaması, uyarı levhalarının bulunmaması, işçilere gereken isg eğitimlerinin detaylı olarak anlatılmamasıdır. İkinci sırada yer alan malzeme düşmesi tipi kazaların nedeni olarak düzensiz çalışma ortamı ve dikkatsizlik olarak değerlendirilmektedir. Malzeme sıçraması tipindeki kazalar kișisel koruyucu ekipmanların kullanılması ile azaltılabilir.

Tablo 2'de Türkiye'de 2016 y1lında inşaat sektörünün bina inşaatı, bina dışı yapıların inşaatı, özel inşaat faaliyetleri bölümlerine göre iş kazası, meslek hastalığı ve ölüm sayıları tüm sektörlerle kıyaslanarak verilmiştir.

Tablo 2. 2016 yılında inşaat sektörü ve Türkiye genelinde meydana gelen iş kazası, meslek hastalığı ve ölüm

\begin{tabular}{cccc}
\multicolumn{4}{c}{ sayıları [17] } \\
\hline Sektörler & İş Kazası & Meslek Hastalı̆̆ı & Ölüm \\
\hline Bina inşaatı & 20.159 & 16 & 239 \\
Bina dışı yapıların inşaatı & 9.516 & 7 & 130 \\
Özel inşaat faaliyetleri & 14.877 & 7 & 127 \\
Tüm İnşaatlar Toplamı & 44.552 & 30 & 496 \\
Tüm Sektörler Toplamı & $\mathbf{2 8 6 . 0 6 8}$ & $\mathbf{5 9 7}$ & $\mathbf{1 . 4 0 5}$ \\
\hline
\end{tabular}

Tüm sektörlere oranlandığında, 2016'da meydana gelen iş kazalarının \% 7,05'ini bina inşaatları, \%3,32'sini bina dışı yapıların inşaatı, \%5,20'sini özel inşaat faaliyetleri oluşturmaktadır. İnşaatın bu üç sektöründe meydana gelen toplam iş kazaları ise tüm sektörlerde meydana gelen iş kazalarının \%15,57'sini oluşturmaktadır.

Tüm sektörlere oranlandığında, 2016'da meydana gelen meslek hastalıklarının \%2,68'ini bina inşaatları, $\% 1,17$ 'sini bina dışı yapıların inşaatı, \%1,17'sini özel inşaat faaliyetleri oluşturmaktadır. İnşaatın bu üç sektöründe meydana gelen toplam meslek hastalığ sayısı ise tüm sektörlerde meydana gelen meslek hastalıklarının \%5,02'sini oluşturmaktadır.
Tüm sektörlere oranlandığında, 2016'da yaşanan ölüm vakalarının \%17,01'ini bina inşaatları, \%9,25'ini bina dışı yapıların inşaatı, \%9,04'ünü özel inşaat faaliyetleri oluşturmaktadır. İnşaatın bu üç sektöründe meydana gelen toplam ölüm sayısı ise tüm sektörlerde yaşanan ölüm vakalarının \%35,30’unu oluşturmaktadır.

Tablo 3'te Türkiye'de 2017 y1lında inşaat sektörünün bina inşaatı, bina dışı yapıların inşaatı, özel inşaat faaliyetleri bölümlerine göre iş kazası, meslek hastalığı ve ölüm sayıları tüm sektörlerle kıyaslanarak verilmiştir.

Tablo 3. 2017 yılında inşaat sektörü ve Türkiye genelinde meydana gelen iş kazası, meslek hastalığı ve ölüm

\begin{tabular}{|c|c|c|c|}
\hline Sektörler & İş Kazası & Meslek Hastalığı & Ölüm \\
\hline Bina inşaatı & 34.952 & 11 & 340 \\
\hline Bina dışı yapıların inşaatı & 20.873 & 3 & 158 \\
\hline Özel inşaat faaliyetleri & 6.977 & 2 & 89 \\
\hline Tüm İnşaatlar Toplamı & 62.802 & 16 & 587 \\
\hline Tüm Sektörler Toplamı & 359.653 & 691 & 1.633 \\
\hline
\end{tabular}

Tüm sektörlere oranlandığında, 2017'de meydana gelen iş kazalarının \%9,72'sini bina inşaatları, \%5,80'ini bina dışı yapıların inşaatı, \%1,94'ünü özel inşaat faaliyetleri oluşturmaktadır. İnşaatın bu üç sektöründe meydana gelen toplam iş kazaları ise tüm sektörlerde meydana gelen iş kazalarının \%17,46'sını oluşturmaktadır.

Tüm sektörlere oranlandığında, 2017'de meydana gelen meslek hastalıklarının \%1,59'unu bina 
inşaatları, \%0,43'ünü bina dışı yapıların inşaatı, $\% 0,29$ 'ini özel inşaat faaliyetleri oluşturmaktadır. İnşaatın bu üç sektöründe meydana gelen toplam meslek hastalığı sayısı ise tüm sektörlerde meydana gelen meslek hastalıklarının \%2,31'ini oluşturmaktadır.

Tüm sektörlere oranlandığında, 2017'de yaşanan ölüm vakalarının \%20,82'sini bina inşaatları, \%9,67'sini bina dışı yapıların inşaatı, \%5,45'ini özel

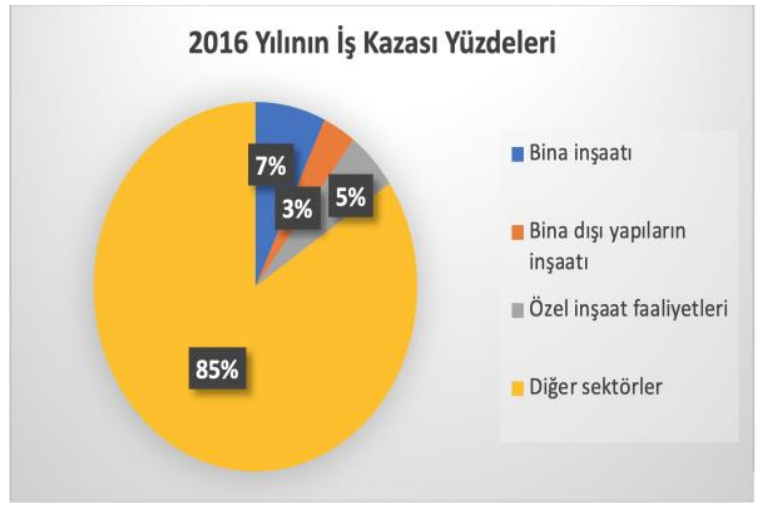

(a) inşaat faaliyetleri oluşturmaktadır. İnşaatın bu üç sektöründe meydana gelen toplam ölüm sayısı ise tüm sektörlerde yaşanan ölüm vakalarının \%35,94'ünü oluşturmaktadır.

2016 ve 2017 yıllarında inşaat sektörünün alt dalları olan bina inşaatı, bina dışı yapıların inşaatı ve özel inşaat faaliyetleri ile diğer sektörlerde meydana gelen iş kazalarının oranları grafik olarak Şekil 1'de gösterilmiştir.

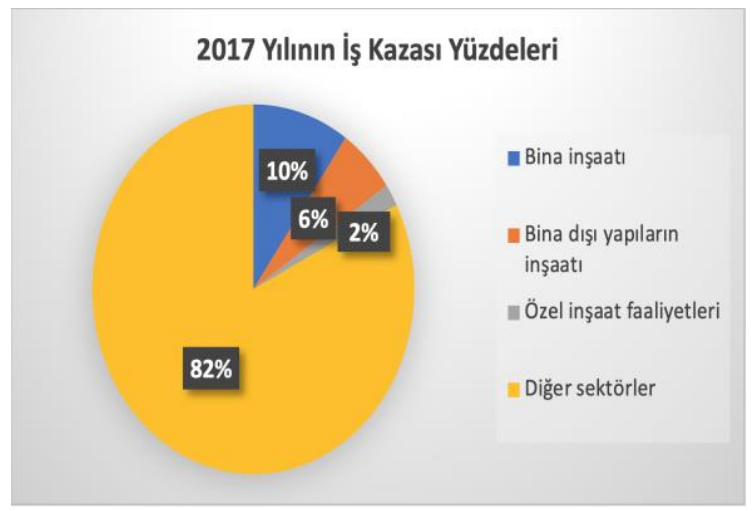

(b)

Şekil 1. Sektörlere göre iş kazası yüzdeleri: (a) 2016 yı11, (b) 2017 yılı [17]

Grafikler incelendiğinde 2017 y1lında, 2016 y1lına oranla bina türü inşaatlar ve bina dışı inşaatlarda kaza miktarı \%3 artmıştır. Buna karşın 2017 yılında, 2016 yılına göre özel inşaat faaliyetlerinde yaşanan iş kazası miktarı $\% 3$ oranında azalmıştır. İş kazası oranı olarak inşaat sektörü, tüm sektörler içerisinde ortalama $\% 16,5^{\prime}$ lik bir paya sahiptir.

Türkiye'de 2016 ve 2017 yıllarında inşaat sektöründe iş kazası geçirenlerin eğitim durumlarına göre sayıları ve oranları Tablo 4'te gösterilmiştir.

Tablo 4. 2016 ve 2017 yıllarında inşaat sektöründe iş kazası geçiren sigortalıların eğitim durumlarına göre

\begin{tabular}{|c|c|c|c|c|}
\hline \multirow[b]{2}{*}{ Eğitim Durumu } & \multicolumn{2}{|l|}{2016} & \multicolumn{2}{|c|}{2017} \\
\hline & $\begin{array}{c}\text { İş Kazası Geçiren } \\
\text { Sigortalı Sayısı }\end{array}$ & $\%$ & $\begin{array}{c}\text { İş Kazası Geçiren } \\
\text { Sigortalı Sayısı }\end{array}$ & $\%$ \\
\hline İlkokul & 14.357 & 32,36 & 19.870 & 31,64 \\
\hline Ortaokul & 7.900 & 17,80 & 12.040 & 19,17 \\
\hline Lise & 7.093 & 15,98 & 11.147 & 17,75 \\
\hline İlköğretim & 4.933 & 11,12 & 5.393 & 8,59 \\
\hline Okur-Yazar & 7.358 & 16,58 & 10.576 & 16,84 \\
\hline Meslek Lisesi & 906 & 2,04 & 1.163 & 1,85 \\
\hline Yüksekokul & 869 & 1,96 & 1.273 & 2,03 \\
\hline Üniversite & 664 & 1,50 & 921 & 1,47 \\
\hline Okur-Yazar Olmayan & 275 & 0,62 & 402 & 0,64 \\
\hline Master, Yüksek Mühendis vb. & 15 & 0,03 & 13 & 0,02 \\
\hline Doktora & 3 & 0,01 & 4 & 0,01 \\
\hline Toplam & 44.373 & 100,00 & 62.802 & 100,00 \\
\hline
\end{tabular}

2016 ve 2017 ylllarında eğitim durumuna göre en çok iş kazası geçiren ilkokul seviyesindeki çalışanlar iken, en az iş kazası geçirenler doktora seviyesindedir. Her iki yılda da bu sıralamanın değişmediği görülmektedir. $\mathrm{Bu}$ tablodan eğitim seviyesi ile iş kazası geçirme ihtimalinin doğrudan ilişkili olduğu 
söylenebilir. Ayrıca eğitim seviyesi yüksek kişilerin de daha az tehlikeli işlerde çalıştığı bilinmektedir.
2016 ve 2017 yıllarında Türkiye'de iş kazası geçirenlerin yaş gruplarına göre dağılımı Tablo 5'te verilmiştir.

Tablo 5. 2016 ve 2017 yıllarında inşaat sektöründe iş kazası geçiren sigortalıların yaşa göre dağılımı [1]

\begin{tabular}{ccccc}
\hline & \multicolumn{2}{c}{$\mathbf{2 0 1 6}$} & \multicolumn{2}{c}{$\mathbf{2 0 1 7}$} \\
\cline { 2 - 5 } Yaş & $\begin{array}{c}\text { İș Kazası Geçiren } \\
\text { Sigortalı Sayısı }\end{array}$ & \% & $\begin{array}{c}\text { İs Kazası Geçiren } \\
\text { Sigortalı Sayısı }\end{array}$ & \% \\
\hline $14-19$ & 2.568 & 5,79 & 4.125 & 6,57 \\
$20-34$ & 21.795 & 49,12 & 31.240 & 49,74 \\
$35-49$ & 14.913 & 33,61 & 20.353 & 32,41 \\
$50-64$ & 4.968 & 11,20 & 6.914 & 11,01 \\
65 ve üstü & 129 & 0,29 & 170 & 0,27 \\
Toplam & $\mathbf{4 4 . 3 7 3}$ & $\mathbf{1 0 0 , 0 0}$ & $\mathbf{6 2 . 8 0 2}$ & $\mathbf{1 0 0 , 0 0}$ \\
\hline
\end{tabular}

2016 ve 2017 yıllarında inşaat sektöründe meydana gelen iş kazaları en çok 20-34 yaş aralığında meydana gelmektedir. Bunun nedeni olarak genç ișçilerin daha ağır işlerde çalıştırıldığı görülmektedir. Ayrıca 20-34 yaş aralığında tecrübesiz işçilerin daha çok olması hata riskini artırmakta ve bu da iş kazalarının meydana gelme olasılığını yükseltmektedir. 35 yaş ve üstü yaş gruplarında iş kazası geçirenlerin sayısının azalması tecrübe ile direkt olarak ilgilidir. Tecrübe arttıkça hata yapma oranı azalmakta ve iş kazası geçirme ihtimalini de azaltmaktadır. Ayrıca 35 yaş ve üstü yaş gruplarında ağır işlerde çalışma oranı daha azdir.

Türkiye'de inşaat sektöründe iş kazası oranının fazla olduğu İstanbul, İzmir, Ankara, Kocaeli ve Bursa illerindeki iş kazası sayıları Tablo 6'da verilmiştir.

Tablo 6. 2016 ve 2017 yıllarında inşaat sektöründe en çok iş kazasının meydana geldiği iller [1]

\begin{tabular}{ccccc}
\hline & \multicolumn{2}{c}{$\mathbf{2 0 1 6}$} & \multicolumn{2}{c}{$\mathbf{2 0 1 7}$} \\
\cline { 2 - 5 } İl & İş Kazası Sayısı & \% & İş Kazası Sayısı & \% \\
\hline İstanbul & 15.843 & 35,70 & 22.887 & 37,24 \\
İzmir & 3.108 & 7,00 & 5.549 & 9,03 \\
Ankara & 4.198 & 9,46 & 4.849 & 7,89 \\
Kocaeli & 1.451 & 3,27 & 2.163 & 3,52 \\
Bursa & 1.496 & 3,37 & 1.895 & 3,08 \\
Toplam & $\mathbf{4 4 , 3 7 3}$ & $\mathbf{1 0 , 0 0}$ & $\mathbf{6 1 . 4 5 0}$ & $\mathbf{1 0 0 , 0 0}$ \\
\hline
\end{tabular}

Hem 2016 hem de 2017 yıllarında inşaat sektöründe meydana gelen iş kazası sayılarına bakıldı̆̆ında birinci sırada İstanbul yer almaktadır. 2016 yılında en çok iş kazasının meydana geldiği ikinci il Ankara iken, 2017 yılında iş kazası sayısındaki artıştan dolayı ikinci sırada İzmir yer almaktadır. 2016 yılında Bursa'da meydana gelen iş kazası sayısı Kocaeli ilinde meydana gelen kaza sayısından daha fazla iken, 2017 yılında Kocaeli ilinde Bursa ilinden daha fazla iş kazası meydana gelmiştir.

Türkiye'de 2013-2017 yılları arasında inşaat sektöründe meydana gelen iş kazası sayıları Şekil 2'de gösterilmiştir.

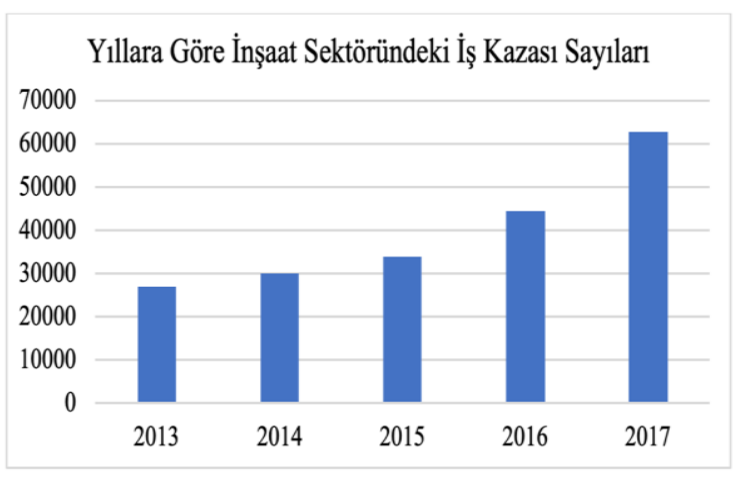

Şekil 2. 2013-2017 yılları arasında inşaat sektöründeki iş kazası sayıları [17] 
Son beş yılda inşaat sektöründe meydana gelen iş kazaları incelendiğinde: 2013 yılında 27.037, 2014 y1linda 30.015, 2015 yilinda 33.979, 2016 yilında $44.552,2017$ yılında 62.802 iş kazası meydana gelmiştir. 2013-2014-2015 yıllarında inşaat sektöründe meydana gelen iş kazası sayısı ortalaması 30.343 iken 2016 ve 2017 yllarında ortalama 53.677 iş kazası meydana gelmiştir. İnşaat sektöründe 2017 yılında meydana gelen iş kazası sayısında, 2016 yılına göre 18.250 artış gözlemlenmiştir.

Türkiye'de iş kazalarının meydana gelme sayıları incelendiğinde başta gelen ilk üç sektör; makine/metal sektörü, inşaat sektörü ve maden sektörüdür. Bu üç sektörün iş kazası sayıları, meslek hastalığı sayıları ve ölüm sayıları Tablo 7'de verilmiştir.

Tablo 7. Türkiye'de en çok iş kazasının meydana geldiği üç sektör [17]

\begin{tabular}{ccccccc}
\hline \multirow{3}{*}{ Sektörler } & \multicolumn{3}{c}{$\mathbf{2 0 1 6}$} & & $\mathbf{2 0 1 7}$ & \\
\cline { 2 - 7 } & İş Kazası & $\begin{array}{c}\text { Meslek } \\
\text { Hastalığı }\end{array}$ & Ölüm & İş Kazası & $\begin{array}{c}\text { Meslek } \\
\text { Hastalığı }\end{array}$ & Ölüm \\
\hline Makine/Metal & 62.264 & 125 & 96 & 73.611 & 177 & 114 \\
İnşaat & 44.552 & 30 & 496 & 62.802 & 16 & 587 \\
Maden & 11.792 & 79 & 83 & 13.052 & 55 & 86 \\
$\begin{array}{c}\text { Tüm Sektörler } \\
\text { Toplamı }\end{array}$ & $\mathbf{2 8 6 . 0 6 8}$ & $\mathbf{5 9 7}$ & $\mathbf{1 . 4 0 5}$ & $\mathbf{3 5 9 . 6 5 3}$ & $\mathbf{6 9 1}$ & $\mathbf{1 . 6 3 3}$ \\
\hline
\end{tabular}

Tablo incelendiğinde ülkemizde hem 2016 hem de 2017 yıllarında en çok iş kazasının meydana geldiği sektör makine/metal sektörüdür. İnşaat sektörü ise iş kazas1 sayısına göre sıralamada ikinci sirada yer almaktadır. Buna karşın, 2016 ve 2017 yıllarında ölümle sonuçlanan kazalarda ilk sırada inşaat sektörünün yer aldı ̆̆ı görülmektedir. Meslek hastalığına yakalanma durumlarına bakıldığında, her iki yıl için de makine/metal ve maden sektörlerinde meslek hastalığı riskinin daha fazla olduğu söylenebilir.

\section{SONUCCLAR}

Kaza türleri incelendiğinde, inşaat sektöründe en fazla meydana gelen iş kazası insan düşmesi tipindeki kazalardır.

2016 ve 2017 'de inşaat sektöründe yaşanan iş kazaları karşılaş̧tırıldığında, 2017 yılında bina inşaatları ve bina dışı inşaatlardaki kazalar \%3 artarken özel inşaatlardaki kazaların \%3 oranında azaldığı görülmektedir.

Eğitim durumlarına göre inşaat sektöründeki iş kazaları incelendiğinde ilk sırada ilkokul eğitim seviyesindeki çalışanların kazaya uğradığı görülmüştür. İşverenlerin iş ile ilgili bilgilendirme ve eğitimlerin artırılması ile eğitim durumu nedeni ile karşılaşılan kazalarda azalma olması öngörülmektedir. Ayrıca eğitim seviyesinin düşük olması öz güven duygusunu da artırmaktadır.

İnşaat sektöründe yaş gruplarına göre iş kazaları incelendiğinde en çok kazaya uğrayan yaş grubunun 20-34 yaş aralığında olduğu sonucuna varılmıştır. Buna göre tecrübesiz çalışanların iş kazasına uğrama olasılığının daha yüksek olduğu söylenebilir.
İllere göre bakıldığında inşaat sektöründe yaşanan en fazla kazanın İstanbul ilinde meydana geldiği belirlenmiştir. İstanbul'da iş kazası miktarının fazla olma nedenleri; nüfus yoğunluğu, kentsel dönüşümden dolayı yapılaşmadaki artış ve büyük şehrin getirdiği stres ortamı olarak gösterilebilir.

2016 ve 2017 yıllarında inşaat sektöründe meydana gelen iş kazaları diğer sektörlerle kıyaslandığında, iş kazası sıralamasında ikinci sırada yer alırken; ölümlü kaza sıralamasında birinci sırada yer almaktadır.

2013-2017 yılları arasında inşaat sektöründe meydana gelen iş kazaları incelendiğinde, kaza sayısı yıllar bazında sürekli artarak 2017 yılında iş kazası miktarında en büyük artış gerçekleşmiştir. Bunun nedeni 2012 yılında iş sağlığ 1 güvenliği kanununun yürürlüğe girmesi ile kazaların kayıt altına alınması ve inşaat sektöründeki hızlı büyümedir.

Tehlikeler ve doğuracağı risklerin detaylı araştırmalar ile tespit edilmesi yeterli önlemler alınabilmesinin ön koşuludur. İş̧ yerlerinde yapılan bu risk değerlendirmeleri uzun bir zaman sürecini kapsamaktadır. Bu şekilde sürekli iyileştirme prensibi hedef edinilerek kalıcı sonuçlar elde edilebilir. Yöneticiler iş yerlerindeki tehlikeler ve riskler hakkında çalışanları bilgilendirmeli, bu konuda eğitimler düzenleyerek risk bilinci oluşturmayı hedeflemelidir. Çalışanların da katkıda bulunması ile tehlikeleri ortadan kaldırmak için yapıcı çözümler üretilmesi sağlanabilir.

Türkiye'de inşaat sektöründeki kazaların azaltılması için gerekli önlemlerin hızlı bir şekilde alınması gerekmektedir. İş sağlığı ve güvenliği bilinci ve kültürünü oluşturmak iş sağllğ 1 ve güvenliği eğitimlerinin artırılması ile sağlanabilecektir. 


\section{KAYNAKLAR}

[1] T.C. Aile, Çalışma ve Sosyal Hizmetler Bakanlığgı. (2019, Ocak). İnşaat Sektöründe İş Sağlığı ve Güvenliği http://www.guvenliinsaat.gov.tr/genelbilgi.html

[2] T.C. Çalışma ve Sosyal Güvenlik Bakanlığı. (2012). İş Sağlığı ve Güvenliğine İlişkin İşyeri Tehlike Sınıfları Tebliği. Resmi Gazete Say1:28509, 26/12/2012.

[3] Betsis, S. Kalogirou, M., Aretoulis, G. \& Pertzinidou M. (2019). Work Accidents Correlation Analysis for Construction Projects in Northern Greece 2003-2007: A Retrospective Study. Safety, 5, 33.

[4] Güllüoğlu, E.N. ve Güllüoğlu, A.N. (2019). Türkiye İnşaat Sektöründe İstihdam ve İş Kazalarının Analizi. Karaelmas İş Sağlığı ve Güvenliği Dergisi, 3(2), 65-81.

[5] Gümüş, R. (2017). Türkiye'de 2015 Y1lında Meydana Gelen İş Kazalarının Analizi ve 2014 Yılı Verileri ile Karşılatırılması. International Journal of Social Science Studuies, 55, 227-287.

[6] Hacıbektaşoğlu, SE. (2018). İnşaat Sektöründe Yaşanan İş Kazalarının Analizi ve Bu Kazalara Neden Olan Etkenlerin İncelenmesi. Stratejik ve Sosyal Araştırmalar Derigisi, 2(3), 159-177.

[7] Çavuş, A. ve Taçgın, E. (2016). Türkiye'de İnşaat Sektöründeki İş Kazalarının Sınıflandırılarak Nedenlerinin İncelenmesi. APJES,IV(II), 13-14.

[8] Bayram, S. (2018). Şantiyelerde Yaşanan Güncel İş Kazaları, Çalışan Farkındalıkları ve Eğitim Seviyeleri Arasındaki İlişki. Çukurova Üniversitesi Mühendislik ve Mimarlık Fakültesi Dergisi, 33(1), 241-252.
[9] Hosseinian, SS. ve Torghabeh, ZJ. (2012). Major Theories Of Construction Accident Causation Models: A Literature Review. International Journal of Advances in Engineering \& Technology, 4(2), 53-66.

[10] Gunduz, M. ve Laitinen, H. (2018). Construction Safety Risk Assessment with Introduced Control Levels. Journal of Civil Engineering and Management, 24(1), 11-18.

[11] İş Sağlığı ve Güvenliği Kanunu. (2019). http://www.mevzuat.gov.tr/MevzuatMetin/1.5.6 331.pdf

[12] Aksoylu, D. (2015). Türkiye'de İnşaat Sektöründeki İş Kazalarının Detaylı Analizi ve Mevzuatın Uygulamadaki Etkinliği. Ankara: Gazi Üniversitesi.

[13] Çiçek, Ö. ve Öçal, M. (2016). Dünyada Ve Türkiye'de İş Sağlığı Ve İş Güvenliğinin Tarihsel Gelişimi. HAK-İŞ Uluslararası Emek ve Toplum Dergisi, 5 (11), 106 - 129.

[14] Ercan, A. (2010). Türkiyede Yapı Sektöründe İşçi Sağlığı ve Güvenliğinin Değerlendirlmesi. Politeknik Dergisi, 13 (1), 19-53.

[15] Mutlu, NG. ve Altuntaş, S. (2017). Türkiye'de 1974-2016 Yıllarında İş Sağlığı ve Güvenliği Alanında Yapılan Lisansüstü Tezlerin Profili. Karaelmas Fen ve Müh. Derg., 7(2), 509-535.

[16] Müngen, U. (2011). İnşaat Sektörümüzdeki Başlıca İş Kazası Tipleri. TMH, İnşaat Mühendisleri Odas1, 496(5), 32-39.

[17] T.C. Sosyal Güvenlik Kurumu. (2018, Kasım). SGK İstatistik Y1llıkları: http://www.sgk.gov.tr/wps/portal/sgk/tr/kurumsa 1/istatistik/sgk_istatistik_yilliklari 